Journal of Arabic Learning

DOI: $10.18860 / \mathrm{ijazarabi.v4i1.10793}$

ISSN(print): 2620-5912 | ISSN(online): 2620-5947

ejournal.uin-malang.ac.id/index.php/ijazarabi/index/ $\mathbf{1 2}$

\title{
Collaborating Digital Social Media for Teaching Science and Arabic in Higher Education during COVID-19 Pandemic
}

\author{
Leon A. Abdillah*1, Trian Handayani' ${ }^{2}$, Ellen R. Rosalyn ${ }^{3}$, Yogi I. Mukti ${ }^{4}$ \\ Universitas Bina Darma, Indonesia ${ }^{1}$, Pegadaian Syariah (Persero) Cps. Simpang \\ Patal, Indonesia ${ }^{2}$, Instalasi Farmasi, RS Ernaldi Bahar, Indonesia ${ }^{3}$, Sekolah Tinggi \\ Teknologi Pagar Alam, Indonesia ${ }^{4}$ \\ leon.abdillah@yahoo.com ${ }^{1}$, trian.handayani@pegadaian.co.id ${ }^{2}$, \\ nellenylasor@gmail.com ${ }^{1}$, yogie.isro.mukti@sttpagaralam.ac.id ${ }^{4}$
}

\begin{abstract}
Globalization does not only involve the spread of massive information technology throughout the world. In the early 2020s the world also experienced a global pandemic COVID-19 which plagues almost all countries in the world. COVID-19 forces learning activities di higher education level to be carried out with social distancing concepts. Online learning can be done using a number of popular information technology applications. The study involved college students from the faculty of computer science and engineering. They took courses on enterprise resource planning, human-computer interaction, and research methods. The results showed that COVID-19 did not impede learning activities. A number of social technologies such as Dropbox, Facebook, Google Forms, Moodle, WhatsApp, WordPress, YouTube, and Zoom have seen a surge in usage to support distance learning activities during the COVID-19 pandemic. With online distance learning mode, all learning activities can be done with the concept of work from home. This learning scheme can be used not only for science and technology fields but also Arabic learning.
\end{abstract}

Keywords: Arabic Learning, COVID-19; Digital Media; Higher Education; YouTube; Zoom.

\section{INTRODUCTION}

The penetration of information technology (IT) in many sectors have been create new place for virtual activities including education process (teaching and learning). Globalization has had a positive impact in the form of equitable distribution of technology throughout the world. One technology that is rapidly reaching into various parts of the world is information technology (IT). IT has become the backbone of modern learning processes. IT provides various advantages to learning systems and has converted the mode of learning styles and approaches (L.A. Abdillah, 2013). The term e-learning has become commonplace in this time of disruption (Nurbayan, Sauri, Hermawan, \& Sanusi4, 2020). In addition, there are many uses of digital systems (Mufidah, Suryawati, Sa'adah, \& Bin Tahir, 2019) and media in learning activities in the 4.0 Industrial Revolution era. 


\section{IJAZ ARABI}

Journal of Arabic Learning

DOI: $10.18860 / \mathrm{ijazarabi.v4i1.10793}$

ISSN(print): $2620-5912$ | ISSN(online): $2620-5947$

ejournal.uin-malang.ac.id/index.php/ijazarabi/index/ $\mathbf{1 3}$

The internet as a part of information technology has become the backbone for various activities. With the internet, sending and processing data can be done regardless of distance, time or territory boundaries of a country or region. Through the internet, communication between educators and students becomes more varied. Many applications that are classified as social technology become online media that can be used to support the learning process. These social technology applications can bridge the learning process for conventional modes with face-to-face systems, as well as for remote modes. Most existing social technologies can be downloaded freely and provide a platform both on a website and mobile basis. Statistics in October describe the situation of the digital world including the use of mobile phones, internet and social media has exceeded $50 \%$ of all (Table 1).

Table 1. World Digital Per October 2020 ((Kemp, 2020))

\begin{tabular}{lccc}
\hline \multicolumn{1}{c}{ Notes } & Total & Urbanization & Penetration \\
\hline Population & 7.81 Billion & $56 \%$ & \\
Unique Mobile Phone Users & 5.20 Billion & & $67 \%$ \\
Internet Users & 4.66 Billion & & $60 \%$ \\
Active Social Media Users & 4.14 Billion & & $63 \%$ \\
\hline
\end{tabular}

Coronavirus Disease 2019 or COVID-19 (L.A. Abdillah, 2020c) become a very frightening specter around the world. In the late 2019 and early 2020 period, the world community was shocked by the appearance of a new virus, originally called the novel corona virus (nCOV2019), from Wuhan, Hubei, China's central region. Wuhan is one of the most populated cities or a megacity like Shanghai and Beijing in China. The virus was given by the World Health Organization (WHO) official name corona disease 2019 or COVID-19 (WHO, 2020c) on 11 February 2020. COVID-19 is an infectious disease similar to influenza caused by severe acute respiratory syndrome coronavirus 2 (SARS-CoV-2) (Lin, Lu, Cao, \& Li, 2020). Transmission of COVID-19 from human to human occurs through droplets or direct contact (Lai, Shih, Ko, Tang, \& Hsueh, 2020), which spreads when someone who is infected with COVID-19 coughs, sneezes or exhales (Williams, 2020).

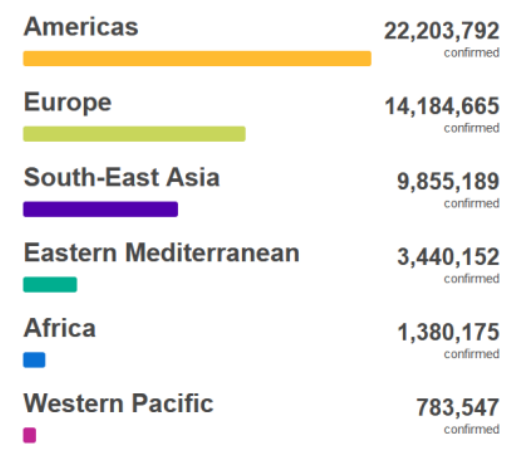

Figure 1. COVID-19 by region (Source: WHO, 2020) 


\section{IJAZ ARABI}

Journal of Arabic Learning

DOI: $10.18860 / \mathrm{ijazarabi.v4i1.10793}$

ISSN(print): $2620-5912$ | ISSN(online): $2620-5947$

ejournal.uin-malang.ac.id/index.php/ijazarabi/index/ $\mathbf{1 4}$

On March 11, 2020, Tedros Adhanom Ghebreyesus, WHO director-general, officially announced the rise in status from epidemic to COVID-19 pandemic status (WHO, 2020b). Epidemic refers to the spread of disease in a community or region that clearly exceeds normal forecasts or a group of epidemics in a number of countries. Once this spread becomes increasingly global and out of control, disease becomes a pandemic. As of November 12, 2020 (WHO, 2020a), 51,848,261 confirmed cases, 1,280,868 deaths, 209 countries, areas or territories with cases. Figure 1 shows the cumulative curve of cases throughout the world.

In more detail for 12 (twelve) countries with the highest rates of COVID19 cases in the world, see Table 1. The highest number of cases is in the United States of America (USA). The case is dominated by countries on the European and America continent. Table 2 shows the list of 12 most frequently found cases of COVID-19 with total cases.

Table 2. Top 12 countries, areas or territories of COVID-19 cases (November 2020)

\begin{tabular}{cllr}
\hline Rank & Country & Continent & \multicolumn{1}{c}{ Cases } \\
\hline 1 & USA & America & $10,124,555$ \\
2 & India & Asia & $8,683,916$ \\
3 & Brazil & America & $5,700,044$ \\
4 & Russia & Europe/Asia & $1,858,568$ \\
5 & France & Europe & $1,829,688$ \\
6 & Spain & Europe & $1,417,709$ \\
7 & Argentina & America & $1,262,476$ \\
8 & UK & Europe & $1,256,729$ \\
9 & Colombia & America & $1,156,675$ \\
10 & Italy & Europe & $1,028,424$ \\
11 & Mexico & America & 978,531 \\
12 & Peru & America & 925,431 \\
\hline
\end{tabular}

This pandemic situation caused almost all human activities normally carried out conventionally to be shifted to a social distancing system that is by "Work from Home" including "Learning from Home". A number of countries apply lockdown for an unspecified amount of time and encourage social distance between individuals. Although in a lockdown condition and maintaining social distancing, but the learning process must still be carried out.

Learning activities usually consist of delivering material by lecturers to students directly in the form of lectures and followed by modification of a number of activities in class. If needed, a number of assignments can be done at home. And at certain times the exam will be carried out, what is a daily exam, midterm, or final semester exams. In a blended learning based learning system, not all meetings are conducted online; face to face activities are also carried out. However, in the global pandemic condition COVID-19 face-to-face meetings were also held in distance mode. The applications that are used to conduct the virtual meetings are Cisco 
IJAZ ARABI

Journal of Arabic Learning

DOI: $10.18860 / \mathrm{ijazarabi.v4i1.10793}$

ISSN(print): $2620-5912$ | ISSN(online): $2620-5947$

ejournal.uin-malang.ac.id/index.php/ijazarabi/index| $\mathbf{1 5}$

Webex, Facebook Live, Google Meet, Instagram Life, Microsoft Teams, Skype, and Zoom.

For some college students or lecturers using the online conference/meeting application may be common, but there are still many who have not used it. The use of devices whether based on desktop, web, or mobile is largely determined by the experience of its users. If the user feels comfortable using an application, he will continue to use it again, even becoming a part of a free mouth-to-mouth campaign to use an application.

Distance learning has become much of a conversation in the world of education and IT which offers modern learning modes. Distance learning or education often illustrates efforts to provide access to learning activities for those who are geographically separated (Moore, Dickson-Deane, \& Galyen, 2011). This research will discuss how the business world of education utilizes information technology in order to prevent the spread of COVID-19 by implementing social distancing while continuing to carry out learning activities.

This study is applying some of social digital media for higher education during COVID-19 in 2020. Some researches was focused only for several activities or using one or two social media for higher education learning activities. There have some limitations related to social media utilization in higher education learning. Therefore this research concerned on the utilization of social media in conducting learning for higher education.

\section{METHOD}

\section{Research Participants and Course Subjects}

The research involved college students come from 2 (two) faculties, namely the faculty of computer science and engineering faculty. They took courses in human-computer interaction (L.A. Abdillah, 2018, 2019a; Dix, Finlay, Abowd, \& Beale, 2004; MacKenzie, 2013), research methods (L.A. Abdillah, 2014c; Berndtsson, Hansson, Olsson, \& Lundell, 2008; Rowlands, Nicholas, Russell, Canty, \& Watkinson, 2011), enterprise resource planning (L.A. Abdillah, 2019b; Monk, Ellen; Bret, 2013; Rashid, Hossain, \& Patrick, 2002), knowledge management systems (L.A. Abdillah, 2014a, 2014b; Awad \& Ghaziri, 2007; Becerra-Fernandez \& Sabherwal, 2015).

This research also visited some Facebook groups for Arabic learning. Arabic is widely used in various countries, especially in the Middle East and North Africa. Based on data from The World FactBook, the CIA page released 27 countries using Arabic as the official language (The World FactBook, 2020). Currently there are 6 (six) official United Nations languages, namely: 1) Arabic, 2) Chinese, 3) English, 4) French, 5) Russian, and 6) Spanish. Arabic officially became the language of the United Nations on 18 December 1973. In Indonesia, the use of Arabic is one of the subjects taught in Islamic religious schools, and in Islamic boarding schools the use of Arabic is a subject that must be followed. 
Journal of Arabic Learning

DOI: $10.18860 / \mathrm{ijazarabi.v4i1.10793}$

ISSN(print): $2620-5912$ | ISSN(onIine): $2620-5947$

ejournal.uin-malang.ac.id/index.php/ijazarabi/index| $\mathbf{1 6}$

Currently, Arabic learning models have also made use of various technologies (Putra, 2020), like social media in the learning process (Setiadi, 2016). Those social media includes: WhatsApp groups, create YouTube channels, Facebook.

\section{Course Periods}

Research carried out during the global pandemic COVID-19 is taking place. In the initial month of lecture the system still uses blended learning. Students come physically to campus and study like normal times. After the COVID-19 period increasingly became, the learning scheme was changed by using the e-learning mode totally. In a blended learning system, some student activities are carried out conventionally, and some are run online. With the global pandemic, the rest of the lecture will be conducted online.

\section{Instruments and Data Collection}

The instruments used in this study include an online questionnaire that was built using Google Forms and distributed online through the Facebook group and WhatsApp group. Meanwhile, to get secondary data, it is done by reading a number of reports and scientific articles related to the research theme.

\section{Social Information Technology}

This research involved 8 (eight) popular information technology applications that were involved in the learning process in higher education during the COVID-19 pandemic. The eight IT-based applications (Figure 2), namely: 1) Moodle, 2) WhatsApp, 3) Facebook, 4) Google Forms, 5) Dropbox, 6) Wordpress, 7) YouTube, and 8) Zoom.

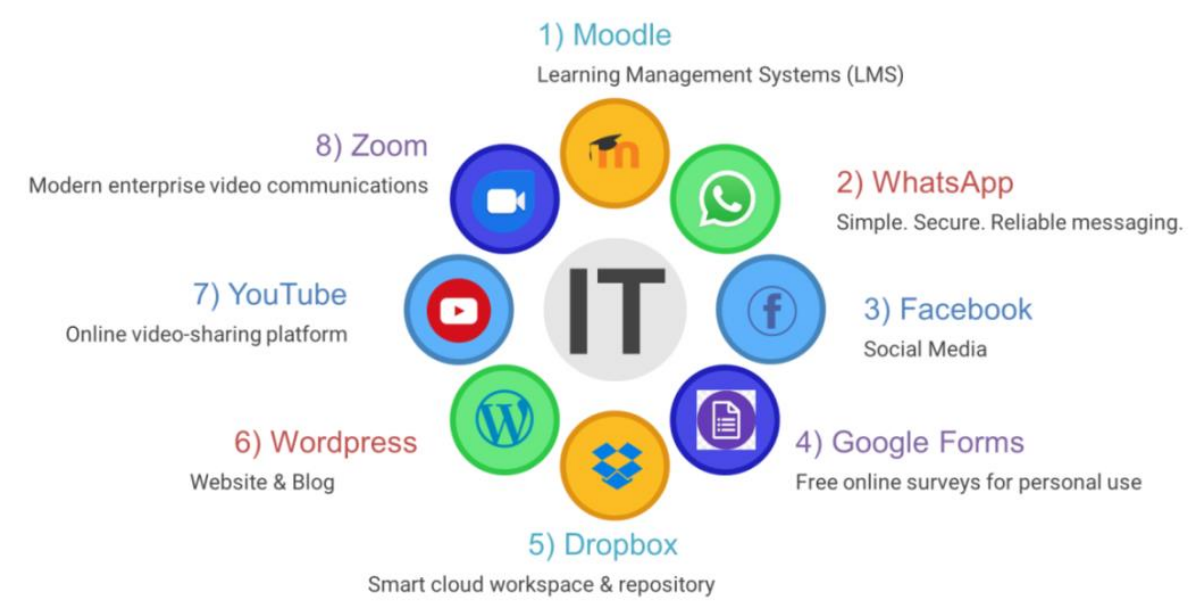

Figure 2. IT used in Higher Education Learning during COVID-19 


\section{RESULTS AND DISCUSSION}

During the global pandemic COVID-19 students were allowed to take lessons wherever they wanted. Overall there are 8 (eight) applications that can be used to support online distance learning activities. The seven applications are summarized in Table 3. Learning activities can use a laptop, smartphone or tablet.

Table 3. Social Technology Supporting Distance Online Learning Activities

\begin{tabular}{|c|c|c|c|c|c|c|}
\hline \multirow[t]{2}{*}{ Apps } & \multicolumn{6}{|c|}{ Activities } \\
\hline & $\mathbf{A}$ & B & $\mathbf{C}$ & $\mathbf{D}$ & $\mathbf{E}$ & $\mathbf{F}$ \\
\hline Dropbox & & & & $\checkmark$ & & \\
\hline Facebook & $\checkmark$ & $\checkmark$ & $\checkmark$ & & & \\
\hline Google Forms & & & & & & $\checkmark$ \\
\hline Moodle & $\checkmark$ & $\checkmark$ & $\checkmark$ & $\checkmark$ & & $\checkmark$ \\
\hline WhatsApp & $\checkmark$ & & & & & \\
\hline Wordpress & $\checkmark$ & & & & $\checkmark$ & \\
\hline YouTube & $\checkmark$ & & & & & \\
\hline Zoom & $\checkmark$ & $\checkmark$ & & $\checkmark$ & & \\
\hline
\end{tabular}

Notes: A: Contents, B: Announcements, C: Attendances, D: Assignments, E: Presentations, and F: Examinations.

\section{Moodle as Virtual Learning Environment}

Conventional learning environments in classrooms are equipped with whiteboard and projector. In IT-based learning mode, Moodle is used to accommodate almost all learning activities. Moodle is free Learning Management Systems (LMS) that is created based on Social Constructionist Pedagogy (Al-Ajlan \& Zedan, 2008). Lecture materials will be delivered in the form of power points, PDFs (L.A. Abdillah, 2012), or YouTube (L.A. Abdillah, 2017; Fleck, Beckman, Sterns, \& Hussey, 2014) videos.

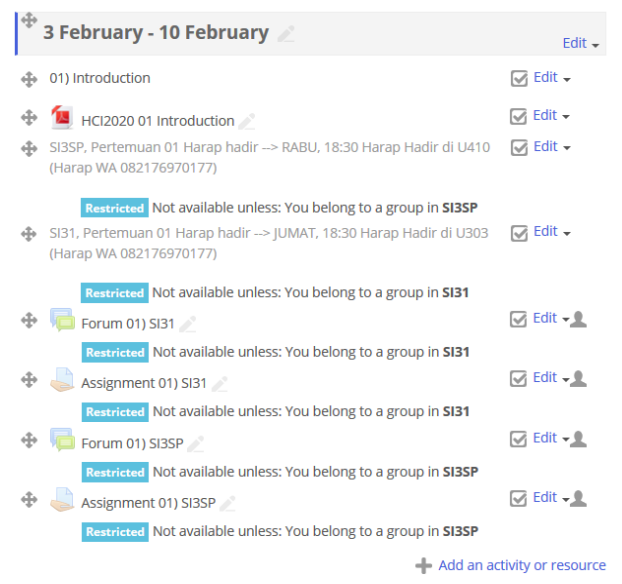

Figure 3. Moodle Virtual Learning Environment

During the global COVID-19 pandemic, many campuses have optimized 


\section{IJAZ ARABI}

Journal of Arabic Learning

DOI: $10.18860 / \mathrm{ijazarabi.v4i1.10793}$

ISSN(print): $2620-5912$ | ISSN(online): $2620-5947$

ejournal.uin-malang.ac.id/index.php/ijazarabi/index/ $\mathbf{1 8}$

Moodle as a Virtual Learning Environments (VLEs) (Costello, 2013). Moodle is an open source VLE or Learning Management System (LMS) which is highly used.

\section{YouTube as Supplementary Learning Environment}

Moodle is used as a principal virtual learning medium. To complement the learning materials, the lecturer has also prepared a YouTube channel which is used to store and distribute lecture materials that can be opened by students and the public at any time. YouTube is equipped with various facilities that can be used to support virtual learning activities. One of the features used is the content grouping feature in the form of a "Playlist" and a comment facility.

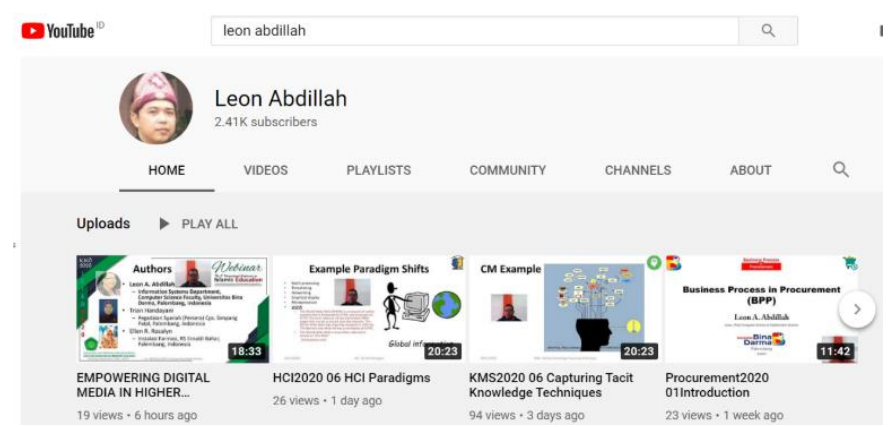

Figure 4. YouTube Content Learning

\section{Attendance by using Moodle, Facebook, and Zoom}

Student learning outcomes are fundamentally seen from the extent to which students are active in learning activities. The attendance shows the concern of students towards the activities around them. In conventional mode, student attendance will be recorded manually based on the physical presence of students in the classroom according to the course schedule. College students who attend will get a score of 1 . If unable to attend due to reasons that can be accounted for as permission for some reason then it can be considered present or given a score of half. Whereas college students who are absent without a clear reason will get a score of 0 , if done exceeds a certain number for example 3 (three) times, then it could be a reduction in the attendance score. During the COVID-19 global pandemic (WHO, 2020b), college students were forbidden from attending crowds on campus or classes. That is why it needs to be accustomed so that attendance is fulfilled without having to gather physically.

To record student attendance without having to do face-to-face activities, lecturers utilize 3 (three) very popular applications, namely Moodle, Facebook and Zoom. The presence of college students can be done by using the forum facilities available at Moodle. Every college student who answers will get his attendance score. Besides using Moodle, attendance can also be done by utilizing Facebook Group, each college student who answers in the comments section will count as his attendance. Facebook is used as a supplementary medium for college students, especially in sharing tacit knowledge (Ractham \& Firpo, 2011). The third 


\section{IJAZ ARABI}

Journal of Arabic Learning

DOI: $10.18860 / \mathrm{ijazarabi.v4i1.10793}$

ISSN(print): $2620-5912$ | ISSN(online): $2620-5947$

ejournal.uin-malang.ac.id/index.php/ijazarabi/index

alternative is to conduct a conference or online meeting using the Zoom application. Zoom is online synchronous meeting tools (SMTs) (Kohnke \& Moorhouse, 2020) that very famous during COVID-19. Zoom provide free slot for everyone with useful features like sharing (Buheji \& Ahmed, 2020), chat, etc. College students who attend online lectures will be counted for attendance.

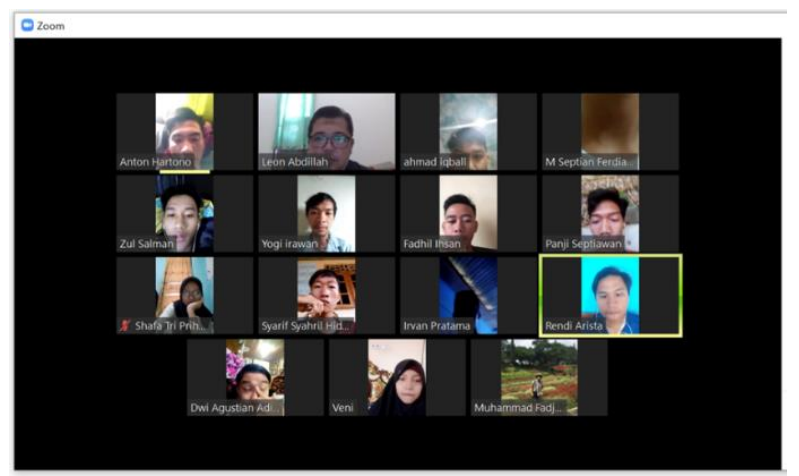

Figure 5. Zoom Meetings

\section{Assignment By Using Moodle, DropBox, and WordPress}

Assignments are activities that are almost present in conventional modes, blended learning, flipped classes, and online learning schemes. Assignments can be used to train college students to work on a number of follow-up activities from the material that has been given, both individually and in group assignments. The assignment of training will train the skill of university students in solving a problem related to their group's topic based on the theories they have given or the theories they have acquired themselves.

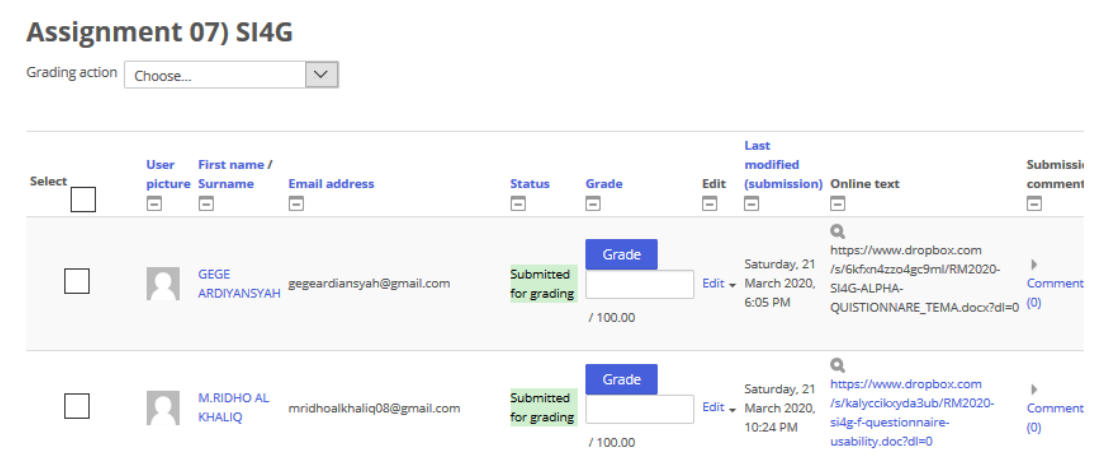

Figure 6. Assignment by using Moodle and DropBox

Moodle provides an activity slot for assignments. Lecturers can give the name of the assignment, its description, and the schedule for when the assignment can be seen, the collection schedule, type of submissions, and other settings. At the time of collection the first assignment will use the facilities in Moodle.

One of the most popular cloud repository is DropBox (L.A. Abdillah, Rofiq, $\&$ Indriani, 2018). DropBox is an online storage media that can be accessed through 
many platforms. DropBox will associate the location of the saved file through a unique Uniform Resource Locator (URL) that can be distributed through any media.

The next alternative is to use WordPress. The bloggers can customize WordPress template and script according to their interest (L.A. Abdillah et al., 2018). This blog application has features that are very rich and easy to use even by college students who are not familiar with web-based programming.

The combination of using DropBox and WordPress (Leon A. Abdillah, 2019; Manca \& Ranieri, 2016) can save storage media, not only on the lecturer side but also on the student side. By utilizing these two social media, students can do their assignments in stages and can be accessed anytime, anywhere.

\section{Presentations By Using YouTube}

The presentation is usually carried out in class in turns by each group. During the COVID-19 pandemic, presentations were made using Zoom media and YouTube. Presentations were made by the student team from their respective homes using the Zoom application. Students are asked to learn how presentations are commonly found on YouTube (Nikolic, Stirling, \& Ros, 2018), then the lecturer will provide references and directions for making video presentations. After getting input and suggestions for improvement from the lecturer, the presentation can be uploaded on YouTube (Figure 7).

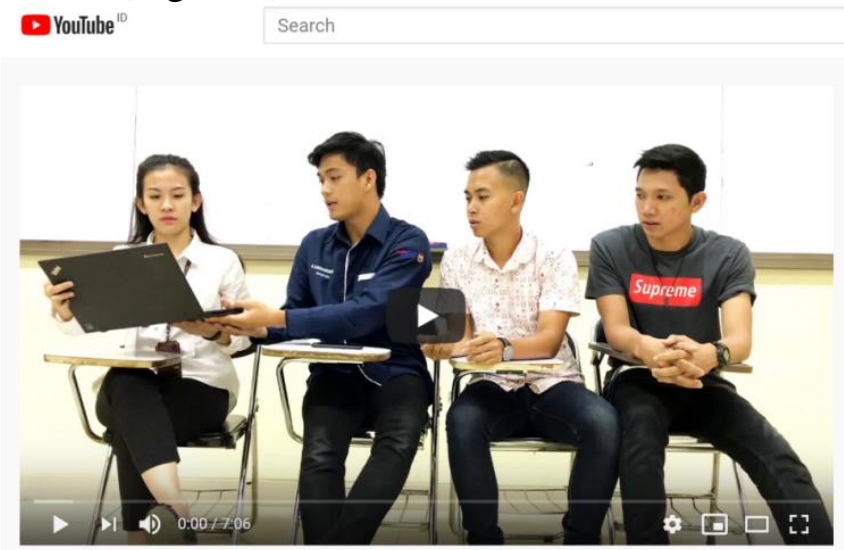

Figure 7. Presentation using YouTube

\section{Examination By Using Google Forms}

Online remote exams can also be done by utilizing the features available on Google Forms (L.A. Abdillah, 2020b). The questions can be in the form of short text, long text, or multiple choices. After all college students have answered all the questions, Google Forms can automatically calculate the total score obtained. The example of Google Forms could be seen in Figure 8. 


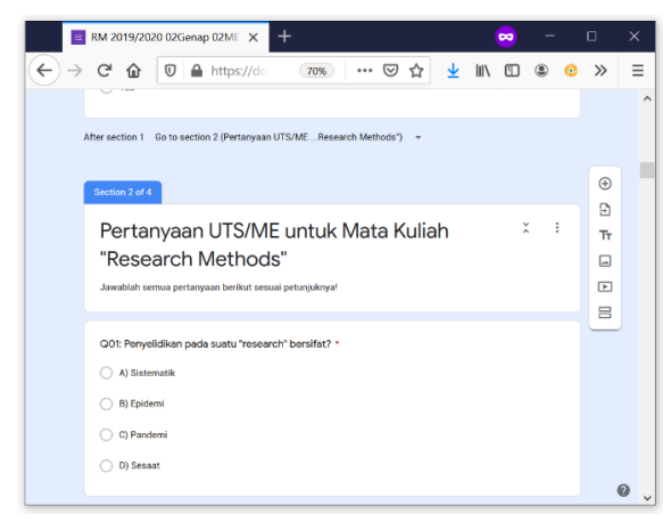

Figure 8. Examination by using Google Forms

\section{Arabic Learning By Using Digital Social Media}

In addition to discussing the use of digital social media in the field of science and technology, this research can also be applied to other fields such as Arabic learning (Mufidah, Bin-tahir, Iqra, \& Maluku, 2018), for example. In the early phase, Arabic learning tends to learn hijaiyah letters (Sobri \& Abdillah, 2013). After studying formal Arabic learning, then it can be continued by studying the Malay Arabic letter (Jawi letter) which is widely used for writing books (Aini \& Abdillah, 2006).

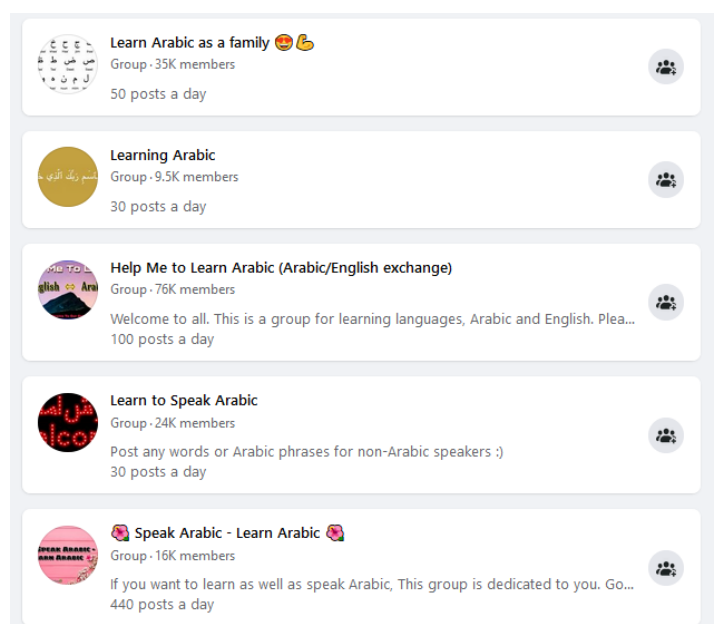

Figure 9. Arabic Learning Facebook Groups

\section{CONCLUSION}

Based on the results and discussion, application of social distancing due to the global pandemic COVID-19 does not prevent learning activities. Zoom is gaining immense popularity during the COVID-19 pandemic. Many information technology applications can be used to carry out distance learning activities (course material dissemination, assignments, presentations, examination) both in synchronous and asynchronous modes. 


\section{IJAZ ARABI}

Journal of Arabic Learning

DOI: $10.18860 / \mathrm{ijazarabi.v4i1.10793}$

ISSN(print): $2620-5912$ | ISSN(online): $2620-5947$

ejournal.uin-malang.ac.id/index.php/ijazarabi/index

The use of digital social media is not only found in the fields of science and technology, but also includes other fields such as Arabic learning. The use of digital social media can be applied during the global pandemic COVID-19 (Mufidah \& Mohammad Idrees, 2020). The limitation of this research is that there are still few participants who have joined in responding to IT-based learning in the global pandemic COVID-19. For further research, it is hoped that more participants can participate in the study, use more unpaid applications, and include user experience (L.A. Abdillah, 2020a) analysis for distance learning.

\section{REFERENCES}

Abdillah, L.A. (2012). PDF articles metadata harvester. Jurnal Komputer Dan Informatika (JKI), 10(1), 1-7. Retrieved from http://arxiv.org/abs/1301.6591

Abdillah, L.A. (2013). Students learning center strategy based on e-learning and blogs. Seminar Nasional Sains Dan Teknologi (SNST) Ke-4 Tahun 2013, F3. 15-20 PDF. Retrieved from http://www.publikasiilmiah.unwahas.ac.id/index.php/PROSIDING_SNST_F T/article/download/761/873

Abdillah, L.A. (2014a). Knowledge Management Systems. Retrieved from Computer Science for Education website: http://blog.binadarma.ac.id/mleonaa/teaching/informationsystems/knowledge-management-systems

Abdillah, L.A. (2014b). Managing information and knowledge sharing cultures in higher educations institutions. The 11th International Research Conference on Quality, Innovation, and Knowledge Management (QIK2014). Bandung: Monash University, Australia \& Universitas Padjadjaran, Indonesia.

Abdillah, L.A. (2014c). Research Methods. Retrieved from http://blog.binadarma.ac.id/mleonaa/teaching/research-methods-metodepenelitian/

Abdillah, L.A. (2017). Enriching Information Technology Course Materials by Using Youtube. The 5th International Conference On Artificial Intelligence, Computer Science and Information Technology (AICSIT2017), 75-82. https://doi.org/https://doi.org/10.6084/m9.figshare.5480125.v1

Abdillah, L.A. (2018). Human-Computer Interaction. Retrieved from https://leonabdillah.wordpress.com/teaching/human-computer-interactionhci/

Abdillah, L.A. (2019a). Analisis Aplikasi Mobile Transportasi Online Menggunakan User Experience Questionnaire pada Era Milenial dan Z. JSINBIS (Jurnal Sistem Informasi Bisnis), 9(2), 204-211. https://doi.org/10.21456/vol9iss2pp204-211

Abdillah, L.A. (2019b). Enterprise Resource Planning. Retrieved from Computer Science \& Information Systems website: https://leonabdillah.wordpress.com/teaching/enterprise-resource-planningerp/ 
IJAZ ARAB I

Journal of Arabic Learning

DOI: $10.18860 / \mathrm{ijazarabi.v4i1.10793}$

ISSN(print): $2620-5912$ | ISSN(online): $2620-5947$

ejournal.uin-malang.ac.id/index.php/ijazarabi/index| 23

Abdillah, L.A. (2020a). FinTech E-Commerce Payment Application User Experience Analysis during COVID-19 Pandemic. Scientific Journal of Informatics (SJI), 7(2), 265-278. https://doi.org/10.15294/sji.v7i2.26056

Abdillah, L.A. (2020b). Green Computer Science Millennial Students Examination. 2nd International Conference on Quran and Hadith Studies Information Technology and Media in Conjunction with the 1st International Conference on Islam, Science and Technology, ICONQUHAS2018 \& ICONIST2018. https://doi.org/10.4108/eai.2-10-2018.2295467

Abdillah, L.A. (2020c). Stigma Terhadap Orang Positif COVID-19. In Pandemik COVID-19: Antara Persoalan dan Refleksi di Indonesia. Medan: Yayasan Kita Menulis.

Abdillah, L.A., Rofiq, A. A., \& Indriani, D. E. (2018). Information Technology Utilization in Environmentally Friendly Higher Education. Proceedings of the Built Environment, Science and Technology International Conference 2018, 350-355. Surabaya: Faculty of Science and Technology (FSTI) The State of Islamic University of Sunan Ampel (UINSA) Surabaya.

Abdillah, Leon A. (2019). Empowering Digital Social Media in Organizing Computer Science Students Higher Education Assignments. The 4th International Conference of Islamic Education (ICIED2019), 426-433. Retrieved from http://conferences.uinmalang.ac.id/index.php/icied/article/download/1056/468

Aini, O. N., \& Abdillah, L. A. (2006). Perangkat Lunak Bantu Mengenal Huruf Arab Melayu Ke Bentuk. Jurnal Ilmiah MATRIK, 8(3), 317-334.

Al-Ajlan, A., \& Zedan, H. (2008). Why moodle. 12th IEEE International Workshop on Future Trends of Distributed Computing Systems, pp. 58-64. https://doi.org/10.1109/FTDCS.2008.22

Awad, E. M., \& Ghaziri, H. M. (2007). Knowledge Management. New Delhi, India: Dorling Kindersley (India) Pvt. Ltd. (Pearson Education).

Becerra-Fernandez, I., \& Sabherwal, R. (2015). Knowledge Management: Systems and Processes (2nd ed.). New York, USA: Routledge (Taylor \& Francis).

Berndtsson, M., Hansson, J., Olsson, B., \& Lundell, B. (2008). Thesis Projects: A Guide for Students in Computer Science and Information Systems. In Thesis Projects. https://doi.org/10.1007/978-1-84800-009-4

Buheji, M., \& Ahmed, D. (2020). Implications of Zoom and Similar Apps on 'Flipclass' Outcome in the New Normal. International Journal of Learning and Development, 10(3), 1. https://doi.org/10.5296/ijld.v10i3.17374

Costello, E. (2013). Opening up to open source: Looking at how Moodle was adopted in higher education. Open Learning, 28(3), 187-200. https://doi.org/10.1080/02680513.2013.856289

Dix, A., Finlay, J., Abowd, G. D., \& Beale, R. (2004). Human-computer interaction. In Systems, Controls, Embedded Systems, Energy, and Machines. https://doi.org/10.1201/9781420037043

Fleck, B. K. B., Beckman, L. M., Sterns, J. L., \& Hussey, H. D. (2014). YouTube 


\section{IJAZ ARAB I}

Journal of Arabic Learning

DOI: $10.18860 / \mathrm{ijazarabi.v4i1.10793}$

ISSN(print): 2620-5912 | ISSN(onIine): 2620-5947

ejournal.uin-malang.ac.id/index.php/ijazarabi/index/24

in the Classroom: Helpful Tips and Student Perceptions. The Journal of Effective Teaching, 14(3), 21-37.

Kemp, S. (2020). Social media users pass the 4 billion mark as global adoption soars. Retrieved November 12, 2020, from We Are Social website: https://wearesocial.com/blog/2020/10/social-media-users-pass-the-4-billionmark-as-global-adoption-soars

Kohnke, L., \& Moorhouse, B. L. (2020). Facilitating Synchronous Online Language Learning through Zoom. RELC Journal. https://doi.org/10.1177/0033688220937235

Lai, C. C., Shih, T. P., Ko, W. C., Tang, H. J., \& Hsueh, P. R. (2020). Severe acute respiratory syndrome coronavirus 2 (SARS-CoV-2) and coronavirus disease2019 (COVID-19): The epidemic and the challenges. International Journal of Antimicrobial Agents, 55(3), 105924. https://doi.org/10.1016/j.ijantimicag.2020.105924

Lin, L., Lu, L., Cao, W., \& Li, T. (2020). Hypothesis for potential pathogenesis of SARS-CoV-2 infection--a review of immune changes in patients with viral pneumonia. Emerging Microbes \& Infections. https://doi.org/10.1080/22221751.2020.1746199

MacKenzie, I. S. (2013). Human-computer interaction: An empirical research perspective. Waltham, MA, USA: Newnes.

Manca, S., \& Ranieri, M. (2016). Facebook and the others. Potentials and obstacles of Social Media for teaching in higher education. Computers and Education, 95, 216-230. https://doi.org/10.1016/j.compedu.2016.01.012

Monk, Ellen; Bret, W. (2013). Concepts in enterprise resorce planning. Boston, MA, USA: Cengage Learning.

Moore, J. L., Dickson-Deane, C., \& Galyen, K. (2011). E-Learning, online learning, and distance learning environments: Are they the same? Internet and Higher Education, 14(2), 129-135. https://doi.org/10.1016/j.iheduc.2010.10.001

Mufidah, N., Bin-tahir, S. Z., Iqra, U., \& Maluku, B. (2018). Arabic Acquisition Through Facebook Group Learning. IJAZ ARABI: Journal of Arabic Learningbi: Journal of Arabic Learning, 1(1), 30-36. Retrieved from http://ejournal.uin-malang.ac.id/index.php/ijazarabi/article/view/4933/6271

Mufidah, N., \& Mohammad Idrees, M. U. H. (2020). Self-Learning Strategy in مهار ات تعليم في الذاتي التعلم استر اتيجية / Teaching Speech Skills to Face COVID 19) لمو اجهة الكلام COVID 19. Ijaz Arabi Journal of Arabic Learning, 3(1), 33-45. https://doi.org/10.18860/ijazarabi.v3i1.10154

Mufidah, N., Suryawati, D., Sa'adah, N., \& Bin Tahir, S. Z. (2019). Learning Arabic Writing Skill Based on Digital Products. Ijaz Arabi Journal of Arabic Learning, 2(2), 185-190. https://doi.org/10.18860/ijazarabi.v2i2.8395

Nikolic, S., Stirling, D., \& Ros, M. (2018). Formative assessment to develop oral communication competency using YouTube: self- and peer assessment in engineering. European Journal of Engineering Education, 43(4), 538-551. https://doi.org/10.1080/03043797.2017.1298569 
Journal of Arabic Learning

DOI: $10.18860 / \mathrm{ijazarabi.v4i1.10793}$

ISSN(print): $2620-5912$ | ISSN(onIine): $2620-5947$

ejournal.uin-malang.ac.id/index.php/ijazarabi/index/25

Nurbayan, Y., Sauri, S., Hermawan, W., \& Sanusi4, A. (2020). An Innovation in Balāgah Wa Uslūbiyyah Course Through Blended Learning. IJAZ ARABI: Journal of Arabic Learning, 3(1), 132-145. Retrieved from http://ejournal.uin-

malang.ac.id/index.php/ijazarabi/article/download/8290/7750

Putra, A. S. (2020). Teknologi Informasi (IT) Sebagai Alat Syiar Budaya Islam Di Bumi Nusantara Indonesia. SINASIS (Seminar Nasional Sains), 1(1), 567573.

Ractham, P., \& Firpo, D. (2011). Using Social Networking Technology to Enhance Learning in Higher Education: A Case Study using Facebook. Proceedings of the 44th Hawaii International Conference on System Sciences. https://doi.org/10.1016/S0022-328X(00)86099-4

Rashid, M., Hossain, L., \& Patrick, J. (2002). The evolution of ERP Systems: A historical perspective. In Enterprise Resource ... (pp. 1-16). Idea Group Publishing.

Rowlands, I., Nicholas, D., Russell, B., Canty, N., \& Watkinson, A. (2011). Social media use in the research workflow. Learned Publishing, 24(3), 183-195. https://doi.org/10.1087/20110306

Setiadi, A. (2016). Pemanfaatan Media Sosial untuk Efektifitas Komunikasi. Cakrawala - Jurnal Humaniora, 16(2), 1-7. Retrieved from https://ejournal.bsi.ac.id/ejurnal/index.php/cakrawala/article/download/1283/ 1055

Sobri, M., \& Abdillah, L. A. (2013). Aplikasi belajar membaca iqro' berbasis mobile 1). Seminar Nasional Teknologi Informasi Dan Multimedia (Semnasteknomedia2013). Retrieved from https://ojs.amikom.ac.id/index.php/semnasteknomedia/article/view/627/603

The World FactBook. (2020). Languages. Retrieved from https://www.cia.gov/library/publications/the-world-factbook/fields/402.html

WHO. (2020a). Coronavirus (Covid-19) Dashboard (New Website). Retrieved April 13, 2020, from https://who.sprinklr.com/\#

WHO. (2020b). WHO Director-General's opening remarks at the media briefing on COVID-19 - 11 March 2020. Retrieved from https://www.who.int/dg/speeches/detail/who-director-general-s-openingremarks-at-the-media-briefing-on-covid-19---11-march-2020

WHO. (2020c). WHO Director-General's remarks at the media briefing on 2019nCoV on 11 February 2020. Retrieved from https://www.who.int/dg/speeches/detail/who-director-general-s-remarks-atthe-media-briefing-on-2019-ncov-on-11-february-2020

Williams, T. (2020). Breaking the chain of infection. Journal of Perioperative Practice, 30(4), 83-84. https://doi.org/10.1177/1750458920914256 